University of Nebraska - Lincoln

DigitalCommons@University of Nebraska - Lincoln

Faculty Publications from the Harold W. Manter Laboratory of Parasitology

8-1989

\title{
Coccidian Parasites (Apicomplexa: Eimeriidae) from Insectivores. VII. Six New Species from the Hairy-Tailed Mole, Parascalops breweri
}

\author{
Paulette L. Ford \\ Rocky Mountain Research Station, Albuquerque Lab, plford@fs.fed.us \\ Donald W. Duszynski \\ University of New Mexico, eimeria@unm.edu
}

Follow this and additional works at: https://digitalcommons.unl.edu/parasitologyfacpubs

Part of the Parasitology Commons

Ford, Paulette L. and Duszynski, Donald W., "Coccidian Parasites (Apicomplexa: Eimeriidae) from Insectivores. VII. Six New Species from the Hairy-Tailed Mole, Parascalops breweri" (1989). Faculty Publications from the Harold W. Manter Laboratory of Parasitology. 154.

https://digitalcommons.unl.edu/parasitologyfacpubs/154

This Article is brought to you for free and open access by the Parasitology, Harold W. Manter Laboratory of at DigitalCommons@University of Nebraska - Lincoln. It has been accepted for inclusion in Faculty Publications from the Harold W. Manter Laboratory of Parasitology by an authorized administrator of DigitalCommons@University of Nebraska - Lincoln. 


\title{
COCCIDIAN PARASITES (APICOMPLEXA: EIMERIIDAE) FROM INSECTIVORES. VII. SIX NEW SPECIES FROM THE HAIRY-TAILED MOLE, PARASCALOPS BREWERI
}

\author{
Paulette L. Ford and Donald W. Duszynski \\ Department of Biology, The University of New Mexico, Albuquerque, New Mexico 87131
}

\begin{abstract}
Sixteen hairy-tailed moles, Parascalops breweri, collected from the northeastern U.S.A. were examined for coccidian oocysts; all were infected with multiple species of coccidia and 3 genera were represented. Two cyclosporans, 2 eimerians, and 2 isosporans are described as new species. Sporulated oocysts of Cyclospora ashtabulensis n. sp. are subspheroid to ellipsoid, $18 \times 14(14-23 \times 11-19) \mu \mathrm{m}$, and sporocysts are ovoid, 12 $\times 7(8-14 \times 5-9) \mu \mathrm{m} ; C$. ashtabulensis was found in 7 of $16(44 \%)$ moles. Sporulated oocysts of Cyclospora parascalopi n. sp. are spheroid, $17 \times 14(13-20 \times 11-20) \mu \mathrm{m}$, and sporocysts are ovoid, $11 \times 7(8-14 \times 5-8)$ $\mu \mathrm{m}$; C. parascalopi was found in 8 of $16(50 \%)$ moles. Sporulated oocysts of Eimeria aethiospora n. sp. are subspheroid to ellipsoid, $19 \times 13(15-24 \times 10-16) \mu \mathrm{m}$, and sporocysts are ovoid, $11 \times 6(8-13 \times 4-7) \mu \mathrm{m} ; E$. aethiospora was found in 4 of $16(25 \%)$ moles. Sporulated oocysts of Eimeria titthus $\mathrm{n}$. sp. are subspheroid, 16 $\times 14(13-19 \times 11-17) \mu \mathrm{m}$, and sporocysts are ellipsoid, $11 \times 6(9-13 \times 4-7) \mu \mathrm{m} ; E$. titthus was found in 4 of $16(25 \%)$ moles. Sporulated oocysts of Isospora ashtabulensis n. sp. are ellipsoid, $20 \times 14(16-24 \times 10-18) \mu \mathrm{m}$, and sporocysts are ovoid, $10 \times 7(7-14 \times 5-10) \mu \mathrm{m} ; I$. ashtabulensis was found in 5 of $16(31 \%) \mathrm{moles}$. Sporulated oocysts of Isospora parascalopi $\mathrm{n}$. sp. are subspheroid, $15 \times 13(12-17 \times 11-15) \mu \mathrm{m}$, and sporocysts are ovoid, $9 \times 6(7-13 \times 5-8) \mu \mathrm{m}$; I. parascalopi was found in 12 of $16(75 \%)$ moles. In addition to these 6 new species, sporulated oocysts of another cyclosporan, another eimerian, and another isosporan were seen, but the number of sporulated oocysts was insufficient for adequate study. The number of coccidians now described from insectivores is $72: 5$ cyclosporans, 47 eimerians, and 20 isosporans.
\end{abstract}

Parascalops breweri (Bachman), the hairytailed mole, is found in the northeastern U.S.A. and southeastern Canada. We have studied this mole and other insectivores by using various parameters (electrophoresis, karyotypes, parasites, etc.) to help determine their evolutionary relationships. Fecal samples taken from the $P$. breweri we collected had at least 9 species of coccidia representing 3 genera: Cyclospora, Eimeria, and Isospora. Six of the species had sufficient numbers of oocysts present to determine they are new species.

\section{MATERIALS AND METHODS}

Hosts were live-trapped in June 1980 and fecal samples collected from them were stored in $2 \%(\mathrm{w} / \mathrm{v})$ aqueous potassium dichromate $\left(\mathrm{K}_{2} \mathrm{Cr}_{2} \mathrm{O}_{7}\right)$. Methods for storing and processing fecal samples upon return to the laboratory and for concentrating, measuring, and photographing oocysts have been described in detail (Duszynski et al., 1982; Stout and Duszynski, 1983). Measurements are in $\mu \mathrm{m}$ with ranges in parentheses following the means. All oocysts were measured and photographed when they were between 2,262 and 2,493 days old. Skeletons, skins, and tissues from all hosts are permanently deposited in the Museum of Southwestern Biology, The University of New Mexico (UNM). Syntypes (=phototypes, see Bandoni and Duszynski [1988]) of sporulated oocysts are deposited in

Received 21 November 1988; revised 21 February 1989; accepted 21 February 1989. the U.S. National Museum (USNM) Parasite Collection, Beltsville, Maryland.

\section{RESULTS}

Nine moles were collected from 3 localities in Franklin County, Massachusetts, and 7 moles were collected from 2 localities in Ashtabula County, Ohio. All $16 P$. breweri had numerous oocysts in their feces representing from 2 to 8 coccidian species in each mole. Nine different coccidian species were identified including $3 \mathrm{cy}-$ closporans, 3 eimerians, and 3 isosporans. Sporulated oocysts in sufficient numbers for careful study and identification were available for only 6 of these species, and all of them are described as new species.

\section{Cyclospora ashtabulensis n. sp.}

(Figs. 1, 2, 16)

\section{Description}

Oocyst subspheroid (Fig. 2) to ellipsoid (Fig. 1) with thick wall $(>1.0)$ composed of 2 layers: outer layer rough, inner layer smooth. Polar body, oocyst residuum, and micropyle absent. Sporulated oocysts $(\mathbf{n}=$ 23) $18.0 \times 14.3(14-23 \times 11-19)$ with $\mathrm{L} / \mathrm{W}$ ratio 1.3 $(1.1-1.7)$; sporocysts $(n=23)$ ovoid, $11.6 \times 7.2(8-14$ $\times$ 5-9) with $\mathrm{L} / \mathrm{W}$ ratio $1.6(1.2-2.0)$; membranous material between sporocysts (Figs. 1,2) appears to hold them together; Stieda body present as crescent-shaped cap covering rounded end of sporocyst (Fig. 1), but sub- and parastieda bodies absent; sporocyst residuum of several large globules that may obscure sporozoites (Fig. 1) or as a compact mass (Fig. 2). 


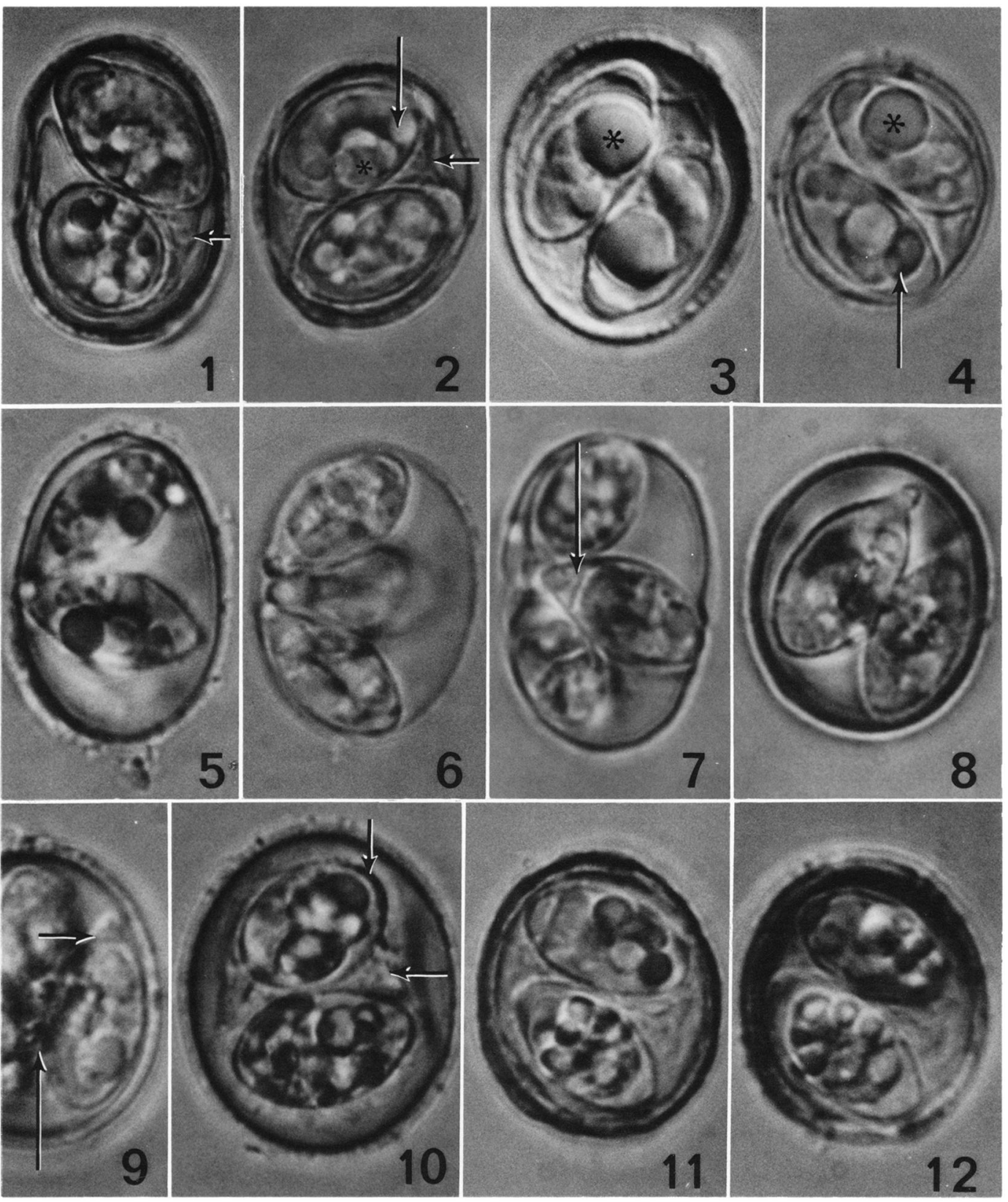

Figures 1-12. Photomicrographs of sporulated oocysts of coccidia collected from the feces of Parascalops breweri. $\times 1,850.1,2$. Cyclospora ashtabulensis $\mathrm{n}$. $\mathrm{sp}$. Note membranous structure between sporocysts (horizontal arrows) and 1 of the 2 sporozoites within the sporocyst (vertical arrow). 3, 4. Cyclospora parascalopi $\mathrm{n}$. sp. Note the large sporocyst residuum $\left(^{*}\right)$ characteristic of this species and sporozoite within the sporocyst (vertical arrow). 5-7. Eimeria aethiospora $\mathrm{n}$. sp. Note that Stieda bodies of all 4 sporocysts always converge to 1 point on oocyst wall; also note substieda body (vertical arrow). 8, 9. Eimeria titthus $\mathrm{n}$. sp. Note nipplelike stieda body, substieda body (horizontal arrow), and granular oocyst residuum (vertical arrow). 10. Isospora ashtabulensis $\mathbf{n}$. $\mathbf{s p}$. Note thickened end of sporocyst forming Stieda body (vertical arrow) and membranous structure (horizontal arrow) between sporocysts. 11, 12. Isospora parascalopi $\mathrm{n}$. sp. Note rounded, domelike Stieda body and sporocyst residuum of large globules. 


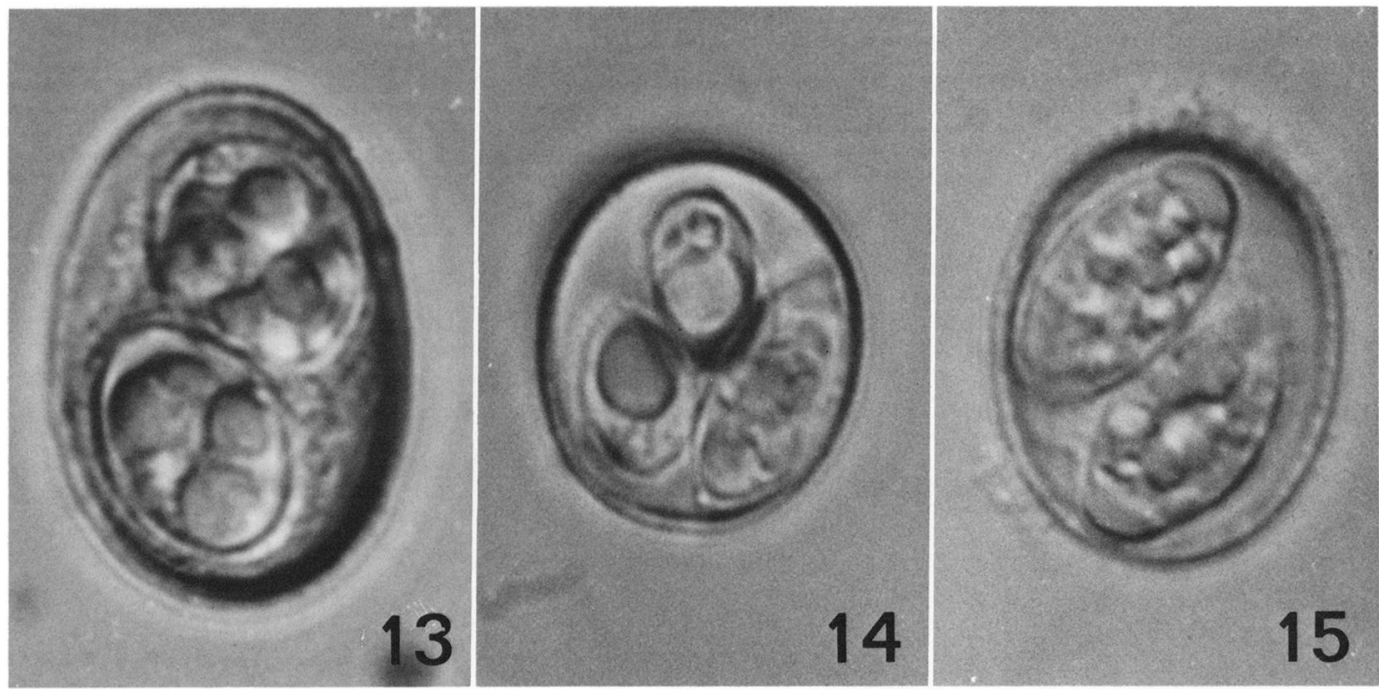

FIGURES 13-15. Photomicrographs of sporulated oocysts of coccidia collected from the feces of Parascalops breweri. $\times 1,850$. 13. Cyclospora sp. 14. Eimeria sp. Note substieda body. 15. Isospora sp. Note rounded Stieda body and granular sporocyst residuum.

\section{Taxonomic summary}

Type host: Parascalops breweri (Bachman, 1842).

Type locality: Ashtabula County, Ohio.

Prevalence: Found in 7 of $16(44 \%)$ P. breweri. All

7 were from Ashtabula County, Ohio.

Site of infection: Unknown, oocysts collected from feces.

Material deposited: Phototypes of oocysts in the USNM Parasite Collection No. 80590. Host skin, skull, skeleton, chromosomes, tissue culture cells, and blood in the Museum of Southwestern Biology, Division of Mammalogy, NK 3121 (male), K. McBee \#120, 29 June 1980, MSB \#43419.

Etymology: The nomen triviale is derived from the name of the county where the host was collected and -ensis (L., belonging to).

\section{Remarks}

Oocysts of this species resemble those of Cyclospora megacephali Ford and Duszynski, 1988, described from the Eastern mole, Scalopus aquaticus (Linnaeus, 1758), because both have an unusual crescentlike Stieda body (Ford and Duszynski, 1988). It differs from C. megacephali by having oocysts that lack polar bodies, have rough outer walls (vs. smooth), and that are slightly smaller $(18 \times 14$ vs. $19 \times 16)$. The sporocysts of $C$. ashtabulensis are less elongate $(12 \times 7)$ than those of C. megacephali $(15 \times 7)$ and thus have a smaller shape index (1.6 vs. 2.1); they also do not have a pointed end opposite the Stieda body.

\section{Cyclospora parascalopi n. sp.}

(Figs. 3, 4, 17)

\section{Description}

Oocyst generally subspheroid with thick wall $(>1.0)$ composed of 2 layers: outer layer striated, slightly sculptured (Fig. 3); inner layer smooth. Oocyst resid- uum, micropyle, and polar body absent. Sporulated oocysts $(n=62) 16.5 \times 13.6(13-20 \times 11-20)$ with $\mathrm{L} / \mathrm{W}$ ratio $1.2(1.0-1.5)$; sporocysts $(\mathrm{n}=62)$ ovoid, $11.1 \times 6.9(8-14 \times 5-8)$ with $\mathrm{L} / \mathrm{W}$ ratio $1.6(1.2-2.0)$; prominent, thick Stieda body present (Fig. 4), but suband parastieda bodies absent; sporocyst residuum a single large sphere (Figs. 3, 4).

\section{Taxonomic summary}

Type host: Parascalops breweri (Bachman, 1842). Type locality: Ashtabula County, Ohio.

Prevalence: Found in 8 of $16(50 \%) P$. breweri, including 2 of $9(22 \%)$ from Franklin County, Massachusetts, and 6 of 7 (86\%) from Ashtabula County, Ohio.

Site of infection: Unknown, oocysts collected from feces.

Material deposited: Phototypes of oocysts in the USNM Parasite Collection No. 80591. Host skin, skull, skeleton, chromosomes, and tissue (heart, kidney, liver) in the Museum of Southwestern Biology, Division of Mammalogy, NK 3109 (female), R. M. Sullivan \#509, 28 June 1980, MSB \#43418.

Etymology: The nomen triviale is derived from the generic name of the host.

\section{Remarks}

Oocysts of this species do not resemble those from any species previously described from insectivores, although they are similar in size to those of $C$. megacephali from $S$. aquaticus (Ford and Duszynski, 1988) and to $C$. ashtabulensis.

\section{Eimeria aethiospora n. sp.} (Figs. 5-7, 18)

\section{Description}

Oocyst subspheroid (rare) to ellipsoid (Figs. 5, 7) with wall $\sim 1.0$ composed of 2 layers of equal thickness: 
outer and inner layers smooth. Polar body present, but oocyst residuum and micropyle absent. Sporulated oocysts $(n=43) 19.3 \times 13.0(15-24 \times 10-16)$ with $\mathrm{L} / \mathrm{W}$ ratio $1.5(1.1-1.8)$; sporocysts $(\mathrm{n}=43)$ pointed at both ends and arranged so that Stieda bodies of all 4 sporocysts converge at 1 point on side of oocyst wall (Figs. 5-7); sporocysts $10.6 \times 5.7(8-13 \times 4-7)$ with $\mathrm{L} / \mathrm{W}$ ratio $1.9(1.4-2.3)$; Stieda and substieda bodies present (Figs. 6, 7), but parastieda body absent; sporocyst residuum of several small globules that may be dispersed or concentrated in a single mass. Sporozoites with a large posterior refractile body.

\section{Taxonomic summary}

Type host: Parascalops breweri (Bachman, 1842). Type locality: Ashtabula County, Ohio.

Prevalence: Found in 4 of $16(25 \%) P$. breweri, including 1 of $9(11 \%)$ from Franklin County, Massachusetts, and 3 of 7 (43\%) from Ashtabula County, Ohio.

Site of infection: Unknown, oocysts collected from feces.

Material deposited: Phototypes of oocysts in the USNM Parasite Collection No. 80589. Host skin, skull, skeleton, chromosomes, and tissue culture cells in the Museum of Southwestern Biology, Division of Mammalogy, NK 3115 (female), R. M. Sullivan \#513, 28 June 1980, MSB \#43417.

Etymology: The nomen triviale is derived from aeth(G., curious, unusual) and spora- (G., seed) to describe the distinctive arrangement of the sporocysts within the oocyst.

\section{Remarks}

Oocysts of this species, because of the unique arrangement of the sporocysts within the oocyst, do not resemble those from any species previously described.

\section{Eimeria titthus n. sp.}

(Figs. 8, 9, 19)

\section{Description}

Oocyst subspheroid with wall $\sim 1.0$ composed of 2 layers: outer layer smooth, light yellow, $\sim 2 / 3$ of total thickness; inner layer smooth. Polar body and micropyle absent, but oocyst residuum present as scattered granules (Fig. 9). Sporulated oocysts $(n=22) 15.8 \times$ $13.5(13-19 \times 11-17)$ with $\mathrm{L} / \mathrm{W}$ ratio $1.2(1.1-1.6)$; sporocysts $(n=21)$ ellipsoid, slightly pointed at end with Stieda body, $11.2 \times 5.8(9-13 \times 4-7)$ with $\mathrm{L} / \mathrm{W}$ ratio 1.9 (1.7-2.3); prominent, nipplelike Stieda body present with small substieda body (Figs. 8, 9), but parastieda body absent; sporocyst residuum consists of a few small dispersed granules. Sporozoites with a posterior refractile body.

\section{Taxonomic summary}

Type host: Parascalops breweri (Bachman, 1842).

Type locality: Ashtabula County, Ohio.

Prevalence: Found in 4 of 16 (13\%) P. breweri, including 1 of $9(11 \%)$ from Franklin County, Massachusetts, and 3 of 7 (43\%) from Ashtabula County, Ohio.

Site of infection: Unknown, oocysts collected from feces.
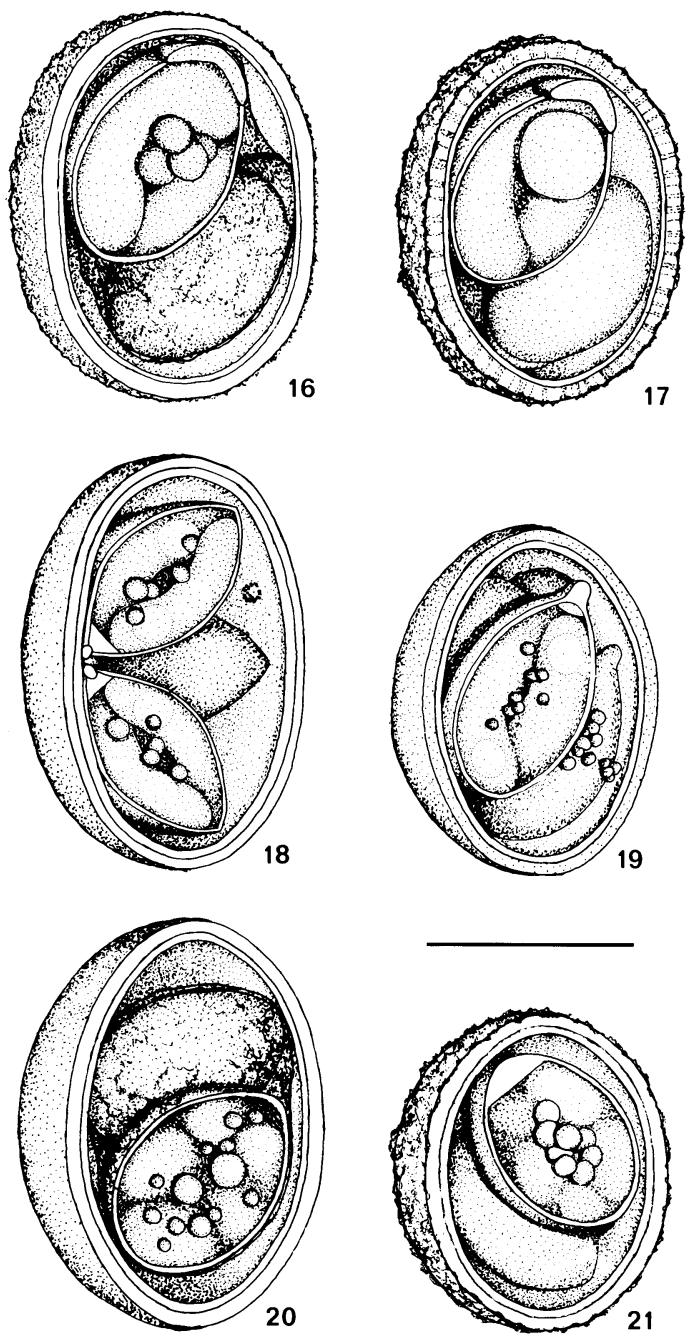

FIGURES 16-21. Line drawings of sporulated oocysts of coccidia collected from feces of Parascalops breweri. Bar $=10 \mu \mathrm{m}$. 16. Cyclospora ashtabulensis. 17. Cyclospora parascalopi. 18. Eimeria aethiospora. 19. Eimeria titthus. 20. Isospora ashtabulensis. 21. Isospora parascalopi.

Material deposited: Phototypes of oocysts in the USNM Parasite Collection No. 80588. Host skin, skull, skeleton, chromosomes, and tissue (heart, kidney, liver) in the Museum of Southwestern Biology, Division of Mammalogy, NK 3109 (female), R. M. Sullivan \#509, 28 June 1980, MSB \#43418.

Etymology: The nomen triviale is derived from titth(G., nipple) to characterize the nipplelike quality of the Stieda body.

\section{Remarks}

Oocysts of this species most closely resemble those of Eimeria bentongi Colley and Mullin, 1971, from the lesser gymnure in Malaya and those of Eimeria neurotrichi Duszynski, 1985, from Neurotrichus gibbsii 
(Baird, 1858) in Oregon and Washington (Colley and Mullin, 1971; Duszynski, 1985). In addition to host and geographic differences, oocysts of $E$. titthus differ from those of $E$. bentongi by having a thinner oocyst wall (1.0 vs. 1.5$)$ with 2 layers (vs. 1), by having sporocysts with a larger $\mathrm{L} / \mathrm{W}$ ratio $(1.9$ vs. 1.7$)$, and by having a substieda body. The only differences between oocysts of $E$. titthus and $E$. neurotrichi are that the former has oocysts with 2 obvious oocyst wall layers and sporocysts with a substieda body, whereas oocysts of $E$. neurotrichi have only 1 thin layer and contain sporocysts without a substieda body.

\section{Isospora ashtabulensis n. sp.}

$$
\text { (Figs. 10, 20) }
$$

\section{Description}

Oocyst subspheroid to ellipsoid with thick $(>1.0)$ wall composed of 2 smooth layers: outer layer $\sim 2 / 3$ of total thickness. Polar body, oocyst residuum, and micropyle absent. Sporulated oocysts $(n=50) 19.7 \times$ $14.4(16-24 \times 10-18)$ with $\mathrm{L} / \mathrm{W}$ ratio $1.4(1.1 \times 1.8)$; sporocysts $(n=46)$ ovoid, $10.2 \times 7.2(7-14 \times 5-9)$ with $\mathrm{L} / \mathrm{W}$ ratio 1.4 (1.1-2.0); membranous material between sporocysts appears to hold them together; Stieda body present as a thickened end of the sporocyst (Fig. 10), but sub- and parastieda bodies absent; sporocyst residuum consists of small dispersed granules, obscuring the 4 sporozoites.

\section{Taxonomic summary}

Type host: Parascalops breweri (Bachman, 1842).

Type locality: Ashtabula County, Ohio.

Prevalence: Found in 5 of $16(31 \%) P$. breweri including 2 of $9(22 \%)$ from Franklin County, Massachusetts, and 3 of 7 (43\%) from Ashtabula County, Ohio. feces.

Site of infection: Unknown, oocysts collected from

Material deposited: Phototypes of oocysts in the USNM Parasite Collection No. 80587. Host skin, skull, skeleton, chromosomes, and tissue (heart, kidney, liver) in the Museum of Southwestern Biology, Division of Mammalogy, NK 3109 (female), R. M. Sullivan \#509, 28 June 1980, MSB \#43418.

Etymology: The nomen triviale is derived from the name of the county where the host was collected and -ensis (L., belonging to).

\section{Remarks}

Oocysts of this species resemble only those of Isospora araneae Golemansky, 1978, from Sorex araneus (L.), but different by having a Stieda body and by lacking a polar body. Golemansky (1978) did not provide a photomicrograph of $I$. araneae, but his line drawing shows 1 end of each sporocyst to be pointed, which is not the case in I. ashtabulensis.

\section{Isospora parascalopi n. sp.} (Figs. 11, 12, 21)

\section{Description}

Oocyst subspheroid with thick $(>1.0)$ wall composed of 2 layers: outer layer sculptured, rough; inner layer smooth. Polar body, micropyle, and oocyst residuum absent. Sporulated oocysts $(n=44) 14.8 \times$
$12.9(12-17 \times 11-15)$ with $\mathrm{L} / \mathrm{W}$ ratio $1.1(1.1-1.3)$; sporocysts $(n=42)$ ovoid, $9.2 \times 6.3(7-13 \times 5-8)$ with $\mathrm{L} / \mathrm{W}$ ratio $1.45(1.1-1.9)$; Stieda body present as rounded dome on sporocyst (Fig. 11), but sub- and parastieda bodies absent; sporocyst residuum consists of 5-10 clumped globules that overlie 4 sporozoites (Figs. 11, 12).

\section{Taxonomic summary}

Type host: Parascalops breweri (Bachman, 1842). Type locality: Ashtabula County, Ohio.

Prevalence: Found in 12 of $16(75 \%) P$. breweri, including 8 of $9(89 \%)$ from Franklin County, Massachusetts, and 4 of 7 (57\%) from Ashtabula County, Ohio.

Site of infection: Unknown, oocysts collected from feces.

Material deposited: Phototypes of oocysts in the USNM Parasite Collection No. 80586. Host skin, skull, skeleton, chromosomes, and blood and tissue culture cells in the Museum of Southwestern Biology, Division of Mammalogy, NK 3121 (male), K. McBee \#120, 29 June 1980, MSB \#43419.

Etymology: The nomen triviale is derived from the generic part of the scientific name of the host

\section{Remarks}

Oocysts of $I$. parascalopi resemble in size only those of Isospora neurotrichi Duszynski, 1985, from N. gibbsii and Isospora dymecodi Duszynski and Moore, 1986, from Dymecadon pilirostris True, 1886 (Duszynski, 1985; Duszynski and Moore, 1986). Both host species are shrew moles from the northwestern U.S.A. and Japan, respectively. Oocysts of I. parascalopi differ from those of $I$. neurotrichi by lacking polar bodies, by the number of oocyst wall layers ( 3 vs. 2 ), and by the difference in the outermost wall layer texture (rough vs. smooth). Also, the Stieda body in I. parascalopi is much larger than that of $I$. neurotrichi. Oocysts of $I$. parascalopi differ from those of $I$. dymecodi by having a mutilayered oocyst wall, by lacking a polar body, and by having sporocysts with Stieda bodies.

\section{Other species \\ (Figs. 13-15)}

In addition to the 6 new species described here, we saw sporulated oocysts representing at least 3 more species, including a Cyclospora sp. (Fig. 13), an Eimeria sp. (Fig. 14), and an Isospora sp. (Fig. 15). Unfortunately, there were not enough of those sporulated oocysts in our samples to permit adequate descriptions.

\section{DISCUSSION}

The hairy-tailed mole, $P$. breweri, is the third of 7 known North American talpids (moles, shrew moles) we have examined for coccidia. This species is fossorial and inhabits well drained forests and open spaces in the northeastern U.S.A. and southeastern Canada; its geographic range overlaps those of 2 other North American moles, Condylura cristata (Linnaeus, 1758) and Scalo- 
pus aquaticus (Linnaeus) (Moore, 1986; Ford and Duszynski, 1988).

Ford and Duszynski (1988) described the coccidia they found in the Eastern mole, $S$. aquaticus, a species that is thought to have shared a common ancestor with $P$. breweri some 16 million yr ago (MYA), based on genetic data and molecular clock theory assembled by Moore (1986). Given that these may be sibling genera and that their modern day ranges overlap, it was interesting to learn that, at least in the animals we sampled, these hosts did not share any coccidian species. On the other hand, a species of cyclosporan in each host species $(C$. ashtabulensis from $P$. breweri and $C$. megacephali from $S$. aquaticus) had oocysts that were very similar in structure. Closely related parasites living in similar environments (e.g., gut cells) in related genetically conservative hosts could be expected to retain many structural similarities. Thus, $C$. ashtabulensis and $C$. megacephali may have shared a common ancestor prior to the divergence of Parascalops and Scalopus some 16 MYA.

Similarly, we notice also the strong structural resemblance of oocysts of 2 coccidians from $P$. breweri to those of 2 coccidians from $N$. gibbsii, a shrew mole confined mainly to Oregon and Washington. According to Moore's genetic analysis (1986), the North American moles are more closely related to the shrew moles (e.g., Neurotrichus) than they are to the Old World moles (e.g., Talpa). Sporulated oocysts of E. titthus and I. parascalopi from $P$. breweri bear a strong structural resemblance to oocysts of $E$. neurotrichi and $I$. neurotrichi, respectively, from $N$. gibbsii, a shrew mole (Duszynski, 1985).

Finally, we have postulated (Duszynski,1986; Ford and Duszynski, 1988) that because of certain genetic, behavioral, and ecologic features, the combination of which are unique to moles, moles will always have very high infection rates with multiple coccidian species. To date, we have examined 171 moles representing 7 species in 5 genera from England, Japan, and the U.S.A.; of these $159(93 \%)$ have been infected and $138(87 \%)$ of the infected moles had from 2 to 8 coccidian species discharging oocysts when examined (Duszynski and Wattam, 1988a, 1988b; Ford and Duszynski, 1988).

\section{ACKNOWLEDGMENTS}

This study was supported partly by NIHDHHS grant 5 S06, RR-08139-07 to the Uni- versity of New Mexico and partly by NSF grant DEB-8004685 to T. L. Yates. Sincere thanks to Drs. D. W. Moore, R. M. Sullivan, and T. L. Yates. Special thanks are due Lynn A. Hertel for the line drawings.

\section{LITERATURE CITED}

BANDONI, S. M., AND D. W. DuszYNSKI. 1988. A plea for improved presentation of type material for coccidia. Journal of Parasitology 74: 519-523.

Colley, F. C., AND S. W. Mullin. 1971. Isospora hylomysis and Eimeria bentongi $\mathrm{n}$. spp. (Protozoa: Eimeriidae) from the lesser gymnure Hylomysis suillus Müller, 1839 in Malaysia. Southeast Asian Journal of Tropical Medicine and Public Health 2: 289-291.

DUSZYNSKI, D. W. 1985. Coccidian parasites (Apicomplexa: Eimeriidae) from insectivores: New species from shrew moles (Talpidae) in the United States. Journal of Protozoology 32: 577-580.

- 1986. Host specificity in the coccidia of small mammals: Fact or fiction? In Advances in protozoological research, Vol. 33, M. Bereczky (ed.). Symposia Biological Hungarica, Akademiai Kiado, Budapest, p. 325-337.

, G. EASTHAM, AND T. L. YATES. 1982. Eimeria from jumping mice (Zapus spp.): A new species and genetic and geographic features of $Z$. hudsonius luteus. Journal of Parasitology 68: 1146-1148.

- AND D. W. MoORE. 1986. Coccidian parasites (Apicomplexa: Eimeriidae) from insectivores. II. Six new species from Japanese shrew moles (Talpidae). Journal of Protozoology 33: 276-281.

- , AND A. R. WATtAM. 1988a. Coccidian parasites (Apicomplexa; Eimeriidae) from insectivores. V. Ten forms from the moles of Japan ( $E u$ roscaptor, Mogera spp.). Journal of Protozoology 35: 55-57.

, AND - 1988b. Coccidian parasites (Apicomplexa: Eimeriidae) from insectivores. IV. Four new species in Talpa europaea from England. Journal of Protozoology 35: 58-62.

FORD, P. L., AND D. W. DUSZYNSKI. 1988. Coccidian parasites (Apicomplexa: Eimeriidae) from insectivores. VI. Six new species from the eastern mole, Scalopus aquaticus. Journal of Protozoology 35: 223-226.

Golemansky, V. 1978. Description de neuf nouvelles espèces de Coccidies (Coccidia: Eimeriidae), parasites de micromammifères en Bulgarie. Acta Protozoologica 17: 261-270.

MOORE, D. W. 1986. Systematic and biogeographic relationships among the Talpinae (Insectivora: Talpidae). Ph.D. Dissertation. The University of New Mexico, Albuquerque, 105 p.

Stout, C. A., AND D. W. DuszYNSKI. 1983. Coccidia from kangaroo rats (Dipodomys spp.) in the western United States, Baja California, and northern Mexico with descriptions of Eimeria merriami sp. $\mathrm{n}$. and Isospora sp. Journal of Parasitology 69: 209-214. 